\title{
Research
}

PY18098

C. Saunders et al.

Primary care experience of chronic illness

\section{Primary care experience of older Australians with chronic illness}

Carla Saunders $^{\mathrm{A}, \mathrm{D}}$, David Carter ${ }^{\mathrm{B}}$ and James J. Brown ${ }^{\mathrm{C}}$

${ }^{A}$ Centre for Health Services Management, Faculty of Health, University of Technology Sydney, Building 10 Jones St Ultimo, NSW 2007, Australia.

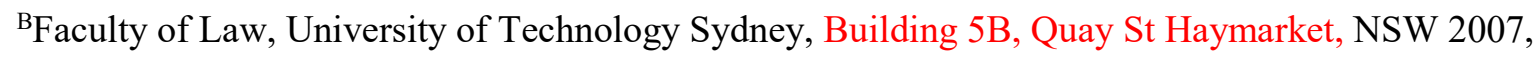
Australia.

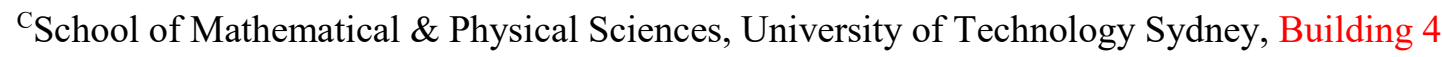
Corner of Thomas St and Harris St, Ultimo, NSW 2007, Australia.

DCorresponding author. Email: Carla.Saunders@uts.edu.au

This large ( $>1000)$ cross-sectional study investigates patient-reported primary care experiences of older people with chronic illness. Previous research has found that approximately half of patients with chronic illness receive optimal chronic illness care and outcomes in Australian general practice. A survey was administered via a double opt-in panel method to people aged $\geq 55$ years who have one or more self-reported major chronic diseases (diabetes and/or chronic heart, kidney, lung, mental health and/or musculoskeletal conditions). Health professionals were found to be important to the majority of Australians surveyed. Well-known chronic illness support resources such as care plans and recalls/reminders were reported to be wanting by up to 50 per cent of respondents. Across all chronic illness groups, $<42$ per cent of respondents reported the provision of information on community resources and 25 per cent reported not having a sound understanding about their medications. Regular local surveys for older people with chronic illness would allow a timely understanding of primary care experiences, needs and preferences of this group, to support quality improvement and drive enhanced patient outcomes.

\section{What is known about the topic?}

- Evidence from older Australians with chronic disease self-reporting the quality of Australian general practice care in terms of the provision of self-management support is extremely limited.

\section{What does this paper add?}

- This research provides valuable insight on the current gaps in general practice self-management support for older Australians with chronic illness. 


\section{Introduction}

The number of Australians with long-term chronic conditions is growing. In 2016, more than one in four people were aged $\geq 55$ years (Australian Bureau of Statistics (ABS) 2016). The trend in older cohorts holding an increasing share of the Australian population will continue for decades, with people aged $\geq 65$ years projected to increase from 3.7 million in 2016 to approximately 5.8 million in 2031 (Australian Institute of Health and Welfare (AIHW) 2016a). The ageing of the population will result in a greater number of people with chronic illnesses, as prevalence of these health problems rises with age. In 2014-15, over 11 million Australians had at least one chronic condition, with approximately 5.3 million having two or more chronic conditions (AIHW 2016b). Chronic illness accounts for the majority of premature deaths, health cost and burden of disease, and are the most common reason for seeking health care (Roxon 2010). Primary care provides the most significant level of care for people with chronic illness outside the home environment, with more than 50 per cent of all GP consultations being for people with chronic health conditions (Roxon 2010).

Actions to improve care for older people with chronic illness focus on comprehensive health care delivered through a variety of approaches by numerous care providers including the patient, through shared decision-making and self-management. Chronic illness self-management has been shown in meta-analysis to result in better outcomes for those affected (Chodosh et al. 2005). To achieve improved outcomes, older people with chronic illness must be involved in self-care, which requires ongoing advice and guidance. Self-care support may vary depending on the nature and severity of chronic health problems; however, there are several fundamental aspects present in all chronic disease self-care support models, such as clear communication, to facilitate health-related conversations and assessments of patient understanding and patient-friendly health information resources (Coleman and Newton 2005). Previous research suggests that only approximately half of patients with chronic illness receive optimal quality of care and associated outcomes in general practice in Australia (Harris and Zwar 2007).

There is growing interest in the healthcare experiences of patients in Australia. Limited aspects of the patient experience in general practice are captured through questions in the Multipurpose Household Survey conducted throughout Australia annually by the Australian Bureau of Statistics, which is a supplement to the monthly Labour Force Survey and is designed to collect statistics for several small, self-contained topics (ABS 2017). Australians aged $\geq 15$ years are included in the Multipurpose Household Survey. The survey asks participants whether they have a long-term condition ('yes' or 'no' question) among several demographic questions. No sub-questions are included on the nature of the chronic illness or on care or support needs in relation to chronic illness. Rather, the patient experience topic covers factors such as time since the patient last saw a GP; frequency of attendance; wait times; reasons for not making appointments or filling scripts when needed, etc. While this multi-topic household survey provides some limited general information regarding patient experience of primary 
Publisher: CSIRO; Journal: PY:Australian Journal of Primary Health

Article Type: Research Paper; Volume: ; Issue: ; Article ID: PY18098 DOI: 10.1071/PY18098; TOC Head:

care in Australia, more focussed information is required if we are to understand and address support and care gaps for older Australians with chronic illness; for example, the occurrence of care plans and referral to community support services (Bodenheimer et al. 2002). This study investigates the primary care experience of older Australians with chronic illnesses to allow a better understanding of the current state of play and opportunities for improvements. Specifically, the research explores the question: what level of evidence-informed resources are provided by general practice to assist older people to better understand and support the self-management of chronic illness in Australia, from the perspective of patients?

\section{Methods}

\section{Participants}

This study investigates the primary care experience of older Australians with either diabetes or chronic heart, kidney, lung, mental health or musculoskeletal conditions. These conditions were chosen due to their high prevalence and contribution to the burden of illness in Australia, and importantly, they require long-term primary care support. Research participants were asked to identify, from the list provided, the chronic illness that was their main concern, with the specific aim of determining the support provided from primary care. For the purposes of this research, 'older' is defined as people aged $\geq 55$ years, based on the self-reported rising prevalence of chronic illness from this age (Williams et al. 2014).

\section{Recruitment}

This investigation utilised a commercial online opt-in research panel administered by PureProfileTM (https://www.pureprofile.com/au/2 to obtain the views of a large cross-section of older Australians aged $\geq 55$ years. The panel survey method has been successfully used in formal research contexts across several social sectors and was viewed to be suited to the purpose of this research (Bambrick et al. 2009). There has been substantial growth in the use of this type of research methodology in the past two decades. Benefits of the method include higher response rates and a reduction in social desirability bias and interviewer effect, which have been found to be common problems with face-to-face methodologies (Duffy et al. 2005). Research supports the reliability of online surveys for behavioural and attitudinal research and to reach particular groups (Braunsberger et al. 2007). The population survey was conducted between November and December 2015. Participants were reimbursed for the online survey completion via a small imbursement of $\sim \$ 1.00$ (\$AU) or by accrual of incentive points. Consent was implied through completion of the online survey. The online panel survey remains open until the required number of participants is reached.

\section{Survey instrument}

The survey tool was adapted from that developed and validated by Glasgow et al. (2000), which explored the use of social and health resources by older people with chronic illness living in the USA. 
Publisher: CSIRO; Journal: PY:Australian Journal of Primary Health

Article Type: Research Paper; Volume: ; Issue: ; Article ID: PY18098 DOI: 10.1071/PY18098; TOC Head:

The current study used the physician and healthcare team questions from the original survey, which also assessed family and friends and neighbourhood/community support and resources. The survey tool utilised a five-point response scale with three descriptive categories; that is, 'not at all' to a 'great deal', with a midpoint of 'a moderate amount'. Basic demographic questions were asked before specific selfcare support experiences with primary care.

\section{Data analysis}

The first stage in the data analysis was the application of a weighting to assist an exploration of a suitably representative sample. The total 2620 preliminary respondents (reporting chronic illness or no chronic illness) were weighted to population benchmarks by age group, gender and state/territory sourced from the Australian Bureau of Statistics quarterly population estimates using ABS.Stat. Weighting used the generalised regression method described in Särndal et al. (2003) to ensure weights aligned with the benchmark distributions. All data are reported as weighted proportions. SPSS version 23 (SPSS Inc., Chicago, IL, USA)was used to conduct descriptive statistics and frequency distributions analyses, applying the identified appropriate weights. Related unweighted sample counts are provided in the tables to permit an understanding of the number of responses on which percentages were calculated.

\section{Ethical clearance}

The University of Technology Sydney Human Research Ethics Committee (ETH15-0073) approved this research.

\section{Results}

Of the 2620 people that responded to the survey by completing the preliminary questions, which included age and gender and a single question asking if they had any of the chronic illnesses (diabetes and/or chronic heart, kidney, lung, mental health and/or musculoskeletal conditions), 1101 respondents identified they had at least one of the chronic conditions under investigation. Table 1 provides key demographics by each 10 -year age grouping from 55 years, including the proportion of participants that reported having a regular primary care practice. The $\geq 75$ year age group comprised the lowest number of survey respondents. Females reported having chronic musculoskeletal conditions at double the rate as males, and reported having long-term mental health and lung problems at $\sim 30 \%$ more often than males. Not having a regular medical home was reported by several respondents across all investigated chronic illnesses, with the highest levels found in those with chronic heart disease (25\%) and diabetes (20\%). Males with heart disease and diabetes were less likely to have a regular primary care practice than females, and females with chronic musculoskeletal, mental health and lung conditions were less likely than men to have a regular practice.

The large majority of respondents across all chronic illnesses identified their health professionals as being important to a large to great extent. Those with chronic musculoskeletal problems were least 
Publisher: CSIRO; Journal: PY:Australian Journal of Primary Health

Article Type: Research Paper; Volume: ; Issue: ; Article ID: PY18098 DOI: 10.1071/PY18098; TOC Head:

likely to consider their health professionals as being important. Notably, in two of the survey questions that assessed health professional communication (i.e. has the health professional thoroughly explained results of tests and has the health professional answered your questions and addressed your concerns), over $70 \%$ of respondents across all conditions reported they had communicated the relevant information to a large or great extent.

Twenty-two per cent, $12 \%$ and $11 \%$ of respondents with chronic kidney problems, chronic musculoskeletal problems and chronic lung problems respectively reported a nil to small extent that their health professional clearly explained what to do to manage their illness. Twenty-nine to over $40 \%$ of respondents across chronic illnesses reported nil to moderate extent that their health professional developed a plan of care with them. Twenty-four to $32 \%$ of respondents across all chronic illness types reported nil to moderate extent that their health professional listened carefully to what they had to say about their illness. Only $76 \%$ of respondents reported they knew enough about the aim of their medications. Nine per cent of chronic heart disease patients reported a nil to small extent in response to the question that assessed understanding of their medications.

Sixty per cent, $58 \%, 55 \%$ and $53 \%$ of respondents with chronic musculoskeletal problems, chronic mental health problems, chronic lung problems and diabetes respectively reported a nil to small extent that their health professional provided support between visits, such as reminder letters or calls. Less than $42 \%$ of respondents across all chronic illness groups reported the provision of information on community resources (e.g. services, education or other resources to assist older Australians to manage their health), with $49 \%, 48 \%$ and $44 \%$ of those with chronic musculoskeletal problems, chronic lung problems and chronic mental health problems respectively reporting a nil to small extent.

Table 2 provides responses for every survey question for each chronic condition under investigation.

\section{Discussion}

There is ample evidence that high levels of primary care support improve self-management and health outcomes in people with chronic illness (Battersby et al. 2010). This research investigated the current levels of support provided by Australian general practice to a large cohort of older Australians with chronic illness. The results support previous research findings of higher rates of morbidity of chronic musculoskeletal conditions among women (Wijnhoven et al. 2006) and less online survey respondents aged $\geq 75$ years (Baker et al. 2003). Overall, in terms of the research question, this study revealed reasonable levels of some fundamental primary care support functions, such as sufficient explanations of test results and responding well to patient concerns. Previous Australian research has found patients consider interpersonal skills of primary care providers, such as listening and other communication skills, to be at least as important as clinical skills (Infante et al. 2004). This research found gaps across several chronic disease support opportunities where it could provide valuable assistance to older Australians with chronic illness while supporting improvements in wider population 
Publisher: CSIRO; Journal: PY:Australian Journal of Primary Health

Article Type: Research Paper; Volume: ; Issue: ; Article ID: PY18098 DOI: 10.1071/PY18098; TOC Head:

health. Care plans have been shown to improve the ability to self-manage illness and resultant health outcomes. Over $30 \%$ of participants reported nil to medium levels of individual care plans (Coulter et al. 2015). Primary care provider communication, particularly in relation to medications and recall/reminders to support regular follow up, were found to be undersupplied. Reducing adverse events from medication errors remains an important patient safety target of government and the health sector overall. As the Australian population continues to age, the numbers of older people prescribed medications in primary care will increase. A sound understanding of medications helps patients to understand why they have been prescribed and how to manage them appropriately (Berkman et al. 2011). Evidence reviews across several the chronic conditions support the role of reminders and follow up of patients in improving health outcomes (McAlister et al. 2001). Similar to a previous Australian study, this research found a gap in the use of community resources to support chronic disease management in primary care (Dennis et al. 2008). Chronic illness support resources provided in local community contexts such as physical activity programs, health advice lines and user-friendly chronic illness information and service directories, provide an additional trustworthy avenue to support patient self-management (Australian Government 2018).

Limited research has found that even when patients receive good self-management support, they may not translate it into everyday activities (Vassilev et al. 2013). However, if patients with chronic illness are not offered self-management support in the first place, any potential to benefit from it is lost, as is the ability for government to address the rising costs of preventable hospitalisation for chronic disease (Australian Institute of Health and Welfare 2018). The demand for hospital and primary health care in older people with chronic illness depends in large part on their abilities to manage and detect increases in severity of chronic illness, with excess demand due to the lack of understanding and skill to selfmanage chronic illness directly affecting healthcare costs (Serper et al. 2014).

Better management of chronic conditions has been flagged by researchers and government alike as one of the critical building blocks to an improved primary healthcare system (Roxon 2010). A more responsive Australian general practice can be achieved through a better understanding of the needs of older patients with chronic illness (Bayliss et al. 2003). Rather than a few general patient-reported experience questions included within a large multipurpose national survey, specific primary care patient surveys are needed to properly inform primary healthcare service quality and patient concerns and needs. Many local health services regularly use surveys to collect information from patients to inform service development and quality improvement, and compared with research, continuous local surveys allow a more nuanced and timely understanding of the experiences, needs and preferences of people with chronic illness. Indubitably, realising the potential of Australian primary care to fully support chronic illness self-management for all patients that could benefit requires known barriers to be addressed, including limited time, increasing workloads, competing priorities and lack of knowledge and skills (Kennedy et al. 2013). 


\section{Strengths and limitations}

Typically, population-based surveys focus on participants who are either $<50$ years or, when investigating age-related issues, over 65 years. A strength of this research is that it captures the experiences of people aged $\geq 55$ years, when chronic illness begins to emerge. The panel survey methodology allows an opportunity to conduct otherwise costly and/or difficult research, and provides access to research participants in shorter timeframes than more traditional non-pre-recruited online or printed postal surveys. However, the cross-sectional design of this research where data are gathered at one point in time and which uses a self-selection, opt-in population panel limits the generalisability of the study findings. Conversely, benchmarking sample estimates to the corresponding population numbers through weighting improves the ability to generalise findings. Some confidence can be gained from similar results found in relation to patient-reported communication in the ABS Multipurpose Household Survey and results of patient-reported self-management support provision in some other research.

\section{Conclusion}

Data and information on the patient-reported quality of Australian general practice care is currently piecemeal and limited. This study provides valuable insight on the current prevalence of support for older Australians with chronic illness from primary medical care settings. Continuous local collections of information from general practice patients with chronic illness is required to ensure transparency and drive improvements in the provision of timely evidence-based care, which, from the perspective of over 1000 older Australians with chronic illness, is not yet fully realised in Australia.

\section{Conflicts of interest}

The authors declare that they have no conflicts of interest.

\section{Acknowledgements}

XXXX This research was funded by a UTS Early Career Research Grant

\section{References}

<eref>Australian Bureau of Statistics (2016) 2017.0 - Census of population and housing: reflecting Australia stories from the Census - snapshot of Australia. (ABS: Belconnen, ACT, Australia) Available at: http://www.abs.gov.au/AUSSTATS/abs@.nsf/DetailsPage/2071.02016?OpenDocument [Verified 12 May $2018]</$ eref $>$

$<$ eref>Australian Bureau of Statistics (2017) 4839.0 - Patient experiences in Australia: summary of findings, 2016-17. Latest issue released Nov. (ABS: Belconnen, ACT, Australia) Available at: www.abs.gov.au/ausstats/abs@.nsf/exnote/4839.0 [Verified 12 May 2018]</eref> <eref>Australian Government (2018) HealthDirect. (Healthdirect: Sydney, NSW, Australia) Available at: https://www.healthdirect.gov.au/management-of-chronic-conditions [Verified 12 May 2018]</eref> 
Publisher: CSIRO; Journal: PY:Australian Journal of Primary Health

Article Type: Research Paper; Volume: ; Issue: ; Article ID: PY18098 DOI: 10.1071/PY18098; TOC Head:

$<$ eref $>$ Australian Institute of Health and Welfare (2016a) Older Australia at a glance (web report). Cat. no. WEB

129. (AIHW: Canberra, ACT, Australia) Available at: www.aihw.gov.au/ageing/older-australia-at-a-glance/

[Verified 10 May 2018]</eref>

$<$ bok $>$ Australian Institute of Health and Welfare (2016b) Australia's health 2016. Australia's health series no. 15.

Cat. no. AUS 199. AIHW, Canberra, ACT, Australia. $</$ bok $>$

Australian Institute of Health 2018. Australia's health series no. 16. AUS 221. Canberra: AIHW.

$<$ jrn>Baker L, Wagner TH, Singer S, Bundorf MK (2003) Use of the Internet and e-mail for health care information: results from a national survey. Journal of the American Medical Association 289(18), 2400-2406. doi:10.1001/jama.289.18.2400</jrn>

$<$ other>Bambrick H, Fear J, Denniss R (2009) What does $\$ 50,000$ buy in a population survey? Characteristics of internet survey participants compared with a random telephone sample. Technical Paper. Oct(5).</other $>$

$<$ jrn>Battersby M, Von Korff M, Schaefer J, Davis C, Ludman E, Greene SM, Wagner EH (2010) Twelve evidence-based principles for implementing self-management support in primary care. Joint Commission Journal on Quality and Patient Safety 36(12), 561-570. doi:10.1016/S1553-7250(10)36084-3</jrn>

$<$ jrn>Bayliss EA, Steiner JF, Fernald DH, Crane LA, Main DS (2003) Descriptions of barriers to self-care by persons with comorbid chronic diseases. Annals of Family Medicine 1(1), 15-21. doi:10.1370/afm.4</jrn>

$<$ jrn>Berkman ND, Sheridan SL, Donahue KE, Halpern DJ, Crotty K (2011) Low health literacy and health outcomes: an updated systematic review. Annals of Internal Medicine 155(2), 97-107. doi:10.7326/0003-4819$\underline{155-2-201107190-00005}</ \mathrm{jrn}>$

$<$ jrn>Bodenheimer T, Lorig K, Holman H, Grumbach K (2002) Patient self-management of chronic disease in primary care. Journal of the American Medical Association 288(19), 2469-2475.

doi:10.1001/jama.288.19.2469</jrn>

$<$ jrn>Braunsberger K, Wybenga H, Gates R (2007) A comparison of reliability between telephone and web-based surveys. Journal of Business Research 60(7), 758-764. doi:10.1016/j.jbusres.2007.02.015</jrn>

$<$ jrn $>$ Chodosh J, Morton SC, Mojica W, Maglione M, Suttorp MJ, Hilton L, Rhodes S, Shekelle P (2005) Metaanalysis: chronic disease self-management programs for older adults. Annals of Internal Medicine 143(6), 427438. doi:10.7326/0003-4819-143-6-200509200-00007</jrn>

$<\mathrm{jrn}>$ Coleman MT, Newton KS (2005) Supporting self-management in patients with chronic illness. American Family Physician 72(8), 1503-1510.</jrn>

$<$ jrn $>$ Coulter A, Entwistle VA, Eccles A, Ryan S, Shepperd S, Perera R (2015) Personalised care planning for adults with chronic or long-term health conditions. Cochrane Database of Systematic Reviews XX, XX-XX. doi:10.1002/14651858.CD010523 $</$ jrn $>$

$<$ jrn>Dennis SM, Zwar N, Griffiths R, Roland M, Hasan I, Davies GP, Harris M (2008) Chronic disease management in primary care: from evidence to policy. The Medical Journal of Australia 188(8), S53.</jrn> 
Publisher: CSIRO; Journal: PY:Australian Journal of Primary Health

Article Type: Research Paper; Volume: ; Issue: ; Article ID: PY18098 DOI: 10.1071/PY18098; TOC Head:

$<$ jrn $>$ Duffy B, Smith K, Terhanian G, Bremer J (2005) Comparing data from online and face-to-face surveys.

International Journal of Market Research 47(6), 615-39. doi:10.1177/147078530504700602</jrn>

$<$ jrn $>$ Glasgow RE, Strycker LA, Toobert DJ, Eakin E. (2000) A social-ecologic approach to assessing support for

disease self-management: the Chronic Illness Resources Survey. Journal of Behavioral Medicine 23(6), 559-

583. doi:10.1023/A:1005507603901</jrn>

$<$ jrn>Harris MF, Zwar NA (2007) Care of patients with chronic disease: the challenge for general practice. The

Medical Journal of Australia 187(2), 104.</jrn>

$<$ jrn>Infante FA, Proudfoot JG, Powell Davies G, Bubner TK, Holton CH, Beilby JJ, Harris MF (2004) How people with chronic illnesses view their care in general practice: a qualitative study. The Medicat Journal of Australia 181(2), 70-73.</jrn>

$<$ jrn>Kennedy A, Bower P, Reeves D, Blakeman T, Bowen R, Chew-Graham C, Lee V (2013) Implementation of self management support for long term conditions in routine primary care settings: cluster randomised controlled trial. BMJ (Clinical Research Ed.) 346, f2882.</jrn>

$<$ jrn>McAlister FA, Lawson FM, Teo KK, Armstrong PW (2001) A systematic review of randomized trials of disease management programs in heart failure. The American Journal of Medicine 110(5), 378-384. doi:10.1016/S0002-9343(00)00743-9 $<$ jrn $>$

$<$ edb $>$ Roxon N (2010) Building a 21st century primary health care system: Australia's first national primary health care strategy. Australian Government Department of Health and Ageing, Canberra, ACT, Australia. $</$ edb $>$

$<$ bok $>$ Särndal CE, Swensson B, Wretman J (2003) Model assisted survey sampling. Springer Science \& Business Media: New York, US .</bok>

$<$ jrn>Serper M, Patzer RE, Curtis LM, Smith SG, O’Conor R, Baker DW, Wolf MS (2014) Health literacy, cognitive ability, and functional health status among elderly patients. Health Services Research 49(4), 12491267. doi:10.1111/1475-6773.12154</jrn>

$<$ jrn>Vassilev I, Rogers A, Blickem C, Brooks H, Kapadia D, Kennedy A, Sanders C, Kirk S, Reeves D (2013) Social networks, the 'work' and work force of chronic illness self-management: a survey analysis of personal communities. PLoS One 8(4), e59723. doi:10.1371/journal.pone.0059723</jrn>

$<$ jrn>Wijnhoven HA, De Vet HC, Picavet HSJ (2006) Prevalence of musculoskeletal disorders is systematically higher in women than in men. The Clinical Journal of Pain 22(8), 717-724. doi:10.1097/01.ajp.0000210912.95664.53</jrn>

$<$ eref $>$ Williams R, Menyen T, Adair T (2014). Health conditions and employment among senior Australians: what are the enablers and barriers to continued engagement in the labour force? (National Seniors Australia:

Brisbane QLD Australia ) Available at: https://nationalseniors.com.au/sites/default/files/140916_NationalSeniorsAustralia_Novartis_HealthConditions Report.pdf [Verified 12 May 2018]</eref> 
Publisher: CSIRO; Journal: PY:Australian Journal of Primary Health

Article Type: Research Paper; Volume: ; Issue: ; Article ID: PY18098

DOI: 10.1071/PY18098; TOC Head:

Table 1. Participant demographics (age, gender and reported chronic illness)

Data are presented as $n$ (\% grand total)

\begin{tabular}{|c|c|c|c|c|c|c|c|c|c|c|c|c|}
\hline & \multirow{2}{*}{\multicolumn{2}{|c|}{$\begin{array}{l}\text { Diabetes } \\
\begin{array}{c}\text { Do you have a } \\
\text { regular general } \\
\text { practice? }\end{array}\end{array}$}} & \multirow{2}{*}{\multicolumn{2}{|c|}{$\begin{array}{c}\text { Chronic heart } \\
\text { Do you have a } \\
\text { regular general } \\
\text { practice? }\end{array}$}} & \multirow{2}{*}{\multicolumn{2}{|c|}{$\begin{array}{c}\text { Chronic kidney } \\
\text { Do you have a } \\
\text { regular general } \\
\text { practice? }\end{array}$}} & \multirow{2}{*}{\multicolumn{2}{|c|}{$\begin{array}{c}\text { Chronic lung } \\
\text { Do you have a } \\
\text { regular general } \\
\text { practice? }\end{array}$}} & \multirow{2}{*}{\multicolumn{2}{|c|}{$\begin{array}{l}\text { Chronic mental } \\
\text { health } \\
\text { Do you have a } \\
\text { regular general } \\
\text { practice? }\end{array}$}} & \multirow{2}{*}{\multicolumn{2}{|c|}{$\begin{array}{l}\begin{array}{l}\text { Chronic } \\
\text { musculoskeletal }\end{array} \\
\begin{array}{c}\text { Do you have a } \\
\text { regular general } \\
\text { practice? }\end{array} \\
\end{array}$}} \\
\hline $\begin{array}{l}\text { Age (years) } \\
\text { /gender }\end{array}$ & & & & & & & & & & & & \\
\hline & Yes & No & Yes & No & Yes & No & Yes & No & Yes & No & Yes & No \\
\hline $\begin{array}{l}\text { Female } \\
55-64 \\
\end{array}$ & $54(17.5)$ & $15(5)$ & $11(7)$ & $5(3)$ & $4(8)$ & $1(2)$ & $22(22)$ & $2(2)$ & $33(35)$ & $4(4)$ & $114(28)$ & $20(5)$ \\
\hline $65-74$ & $43(14)$ & $5(2)$ & $14(10)$ & $6(4)$ & $6(12)$ & $3(6)$ & $22(22)$ & $6(6)$ & $14(15)$ & $2(2)$ & $100(25)$ & $18(4)$ \\
\hline $75+$ & $10(3)$ & $0(0)$ & $8(5)$ & $3(3)$ & $3(6)$ & $1(2)$ & $2(2)$ & $2(2)$ & $1(1)$ & $1(1)$ & $21(5)$ & $5(1)$ \\
\hline All ages & $107(35)$ & $20(6)$ & $33(22)$ & $14(10)$ & $13(27)$ & $5(10)$ & $46(47)$ & $10(10)$ & $48(51)$ & $7(7)$ & $235(58)$ & $43(11)$ \\
\hline Total & \multicolumn{2}{|c|}{$127(41)$} & \multicolumn{2}{|c|}{$47(32)$} & \multicolumn{2}{|c|}{$18(37)$} & \multicolumn{2}{|c|}{$56(57)$} & \multicolumn{2}{|c|}{$55(58)$} & \multicolumn{2}{|c|}{$\begin{array}{l}278(69) \\
\end{array}$} \\
\hline $\begin{array}{l}\text { Male } \\
55-64\end{array}$ & $65(21)$ & $18(6)$ & $34(23)$ & $8(5)$ & $10(20)$ & $3(6)$ & $14(14)$ & $1(1)$ & $21(22)$ & $5(5)$ & 48 (12) & $7(2)$ \\
\hline $65-74$ & $54(17.5)$ & $15(5)$ & 28 (19) & $9(6)$ & $10(20)$ & $3(6)$ & $14(14)$ & $6(6)$ & $8(8)$ & $5(5)$ & $44(11)$ & $11(3)$ \\
\hline $75+$ & $22(7)$ & $7(2)$ & $16(11)$ & $5(3)$ & $5(10)$ & - & $6(6)$ & $1(1)$ & $1(1)$ & - & $14(3)$ & $2(0.05)$ \\
\hline All ages & $141(46)$ & $40(13)$ & $78(53)$ & $22(15)$ & $25(51)$ & $6(12)$ & $34(35)$ & $8(8)$ & $30(32)$ & $10(10)$ & $106(30)$ & $20(5)$ \\
\hline Total & \multicolumn{2}{|c|}{$181(59)$} & \multicolumn{2}{|c|}{$100(68)$} & \multicolumn{2}{|c|}{$31(32)$} & \multicolumn{2}{|c|}{$42(43)$} & \multicolumn{2}{|c|}{$40(42)$} & \multicolumn{2}{|c|}{$126(31)$} \\
\hline $\begin{array}{l}\text { Total (both } \\
\text { sexes) }\end{array}$ & $248(80)$ & $60(20)$ & $111(75)$ & $36(25)$ & $38(78)$ & $11(22)$ & $80(82)$ & $18(18)$ & $78(82)$ & $17(18)$ & $341(84)$ & $63(16)$ \\
\hline Grand total (all) & \multicolumn{2}{|c|}{$308(28)$} & \multicolumn{2}{|c|}{$147(13)$} & \multicolumn{2}{|c|}{$49(4)$} & \multicolumn{2}{|c|}{$98(9)$} & \multicolumn{2}{|c|}{$95(9)$} & \multicolumn{2}{|c|}{$404(37)$} \\
\hline
\end{tabular}

Table 2. Primary healthcare experience by chronic illness type

Data are presented as $n(\%$ total $)$

\begin{tabular}{|c|c|c|c|c|c|c|c|}
\hline $\begin{array}{l}\text { If you have not had any doctor visits } \\
\text { in the past } 6 \text { months, think back to } \\
\text { your last visit: }\end{array}$ & Patient rating & Diabetes & Chronic heart & Chronic kidney & Chronic lung & $\begin{array}{l}\text { Chronic mental } \\
\text { health }\end{array}$ & $\begin{array}{l}\text { Chronic } \\
\text { musculoskeletal }\end{array}$ \\
\hline \multirow[t]{2}{*}{$\begin{array}{l}\text { How important to you is your doctor } \\
\text { or other health professional (e.g. }\end{array}$} & $\begin{array}{l}\text { Nil to a small } \\
\text { extent }\end{array}$ & $12(4)$ & $1(0.6)$ & $1(2)$ & $4(4)$ & $4(4)$ & $22(5)$ \\
\hline & Moderate extent & $40(13)$ & $14(10)$ & $3(6)$ & $7(7)$ & $6(6)$ & $63(16)$ \\
\hline
\end{tabular}


Publisher: CSIRO; Journal: PY:Australian Journal of Primary Health Article Type: Research Paper; Volume: ; Issue: ; Article ID: PY18098

DOI: 10.1071/PY18098; TOC Head:

\begin{tabular}{|c|c|c|c|c|c|c|c|}
\hline $\begin{array}{l}\text { nurse, dietician) in managing your } \\
\text { illness? }\end{array}$ & $\begin{array}{l}\text { Large to great } \\
\text { extent }\end{array}$ & $256(83)$ & $132(89)$ & $45(92)$ & $87(88)$ & $85(90)$ & $319(79)$ \\
\hline & Total & 308 & 147 & 49 & 98 & 95 & 404 \\
\hline \multirow{3}{*}{$\begin{array}{l}\text { Has your doctor or other health } \\
\text { professional (e.g. nurse, dietician) } \\
\text { clearly explained what you needed } \\
\text { to do to manage your illness? }\end{array}$} & $\begin{array}{l}\text { Nil to a small } \\
\text { extent }\end{array}$ & $27(9)$ & $9(6)$ & $4(22)$ & $11(11)$ & $6(6)$ & 47 (12) \\
\hline & Moderate extent & $93(30)$ & $36(24)$ & $9(18)$ & $20(20)$ & $29(30)$ & $130(32)$ \\
\hline & $\begin{array}{l}\text { Large to great } \\
\text { extent }\end{array}$ & $188(61)$ & $102(69)$ & $36(73)$ & $67(68)$ & $60(63)$ & $227(56)$ \\
\hline$+y_{1}$ & Total & 308 & 147 & 49 & 98 & 95 & 404 \\
\hline \multirow{4}{*}{$\begin{array}{l}\text { Has your doctor or other health } \\
\text { professional (e.g. nurse, dietician) } \\
\text { developed a plan of your care with } \\
\text { you? }\end{array}$} & $\begin{array}{l}\text { Nil to a small } \\
\text { extent }\end{array}$ & $38(12)$ & $21(14)$ & $8(16)$ & $19(19)$ & $15(16)$ & $80(20)$ \\
\hline & Moderate extent & 57 (19) & $32(22)$ & $6(13)$ & $19(19)$ & $21(22)$ & $84(21)$ \\
\hline & $\begin{array}{l}\text { Large to great } \\
\text { extent }\end{array}$ & $213(69)$ & $94(64)$ & $35(71)$ & $60(62)$ & $59(62)$ & $240(59)$ \\
\hline & Total & 308 & 147 & 49 & 98 & 95 & 404 \\
\hline \multirow{4}{*}{$\begin{array}{l}\text { Has your doctor or other health } \\
\text { professional (e.g. nurse, dietician) } \\
\text { listened carefully to what you had to } \\
\text { say about your illness? }\end{array}$} & $\begin{array}{l}\text { Nil to a small } \\
\text { extent }\end{array}$ & $25(8)$ & $8(5)$ & $1(2)$ & $9(9)$ & $8(8)$ & $41(10)$ \\
\hline & Moderate extent & $75(24)$ & $29(20)$ & $11(22)$ & $18(18)$ & $18(19)$ & $81(20)$ \\
\hline & $\begin{array}{l}\text { Large to great } \\
\text { extent }\end{array}$ & $208(68)$ & $110(75)$ & $37(76)$ & $71(72)$ & $69(73)$ & $282(70)$ \\
\hline & Total & 308 & 147 & 49 & 98 & 95 & 404 \\
\hline \multirow{4}{*}{$\begin{array}{l}\text { Has your doctor or other health } \\
\text { professional (e.g. nurse, dietician) } \\
\text { provided support between visits; that } \\
\text { is, calls, reminder letters or } \\
\text { newsletters? }\end{array}$} & $\begin{array}{l}\text { Nil to a small } \\
\text { extent }\end{array}$ & $162(53)$ & $69(47)$ & $18(37)$ & $54(55)$ & $55(58)$ & $243(60)$ \\
\hline & Moderate extent & $55(18)$ & $34(23)$ & $12(24)$ & $19(19)$ & $19(20)$ & $72(18)$ \\
\hline & $\begin{array}{l}\text { Large to great } \\
\text { extent }\end{array}$ & $91(29)$ & $44(30)$ & $19(39)$ & $25(25)$ & $21(22)$ & $89(22)$ \\
\hline & Total & 308 & 147 & 49 & 98 & 95 & 404 \\
\hline \multirow[t]{4}{*}{$\begin{array}{l}\text { Have you felt you know enough } \\
\text { about what your medicines are for? }\end{array}$} & $\begin{array}{l}\text { Nil to a small } \\
\text { extent }\end{array}$ & $21(7)$ & $13(9)$ & $2(4)$ & $7(7)$ & $7(7)$ & $30(7)$ \\
\hline & Moderate extent & $59(19)$ & $14(10)$ & $7(14)$ & $12(13)$ & $17(18)$ & $75(19)$ \\
\hline & $\begin{array}{l}\text { Large to great } \\
\text { extent }\end{array}$ & $228(74)$ & $120(82)$ & $40(82)$ & $79(79)$ & $71(75)$ & $299(74)$ \\
\hline & Total & 308 & 147 & 49 & 98 & 95 & 404 \\
\hline \multirow{3}{*}{$\begin{array}{l}\text { Has your doctor or other health } \\
\text { professional answered your } \\
\text { questions and addressed your } \\
\text { concerns? }\end{array}$} & $\begin{array}{l}\text { Nil to a small } \\
\text { extent }\end{array}$ & $29(9)$ & $8(5)$ & $2(4)$ & $7(7)$ & $5(5)$ & $39(10)$ \\
\hline & Moderate extent & $56(19)$ & $27(18)$ & $8(16)$ & $20(20)$ & $21(22)$ & $69(17)$ \\
\hline & $\begin{array}{l}\text { Large to great } \\
\text { extent }\end{array}$ & $223(72)$ & $112(77)$ & $39(80)$ & $71(71)$ & $69(73)$ & $296(73)$ \\
\hline
\end{tabular}


Publisher: CSIRO; Journal: PY:Australian Journal of Primary Health Article Type: Research Paper; Volume: ; Issue: ; Article ID: PY18098 DOI: 10.1071/PY18098; TOC Head:

\begin{tabular}{|c|c|c|c|c|c|c|c|}
\hline & Total & 308 & 147 & 49 & 98 & 95 & 404 \\
\hline \multirow{4}{*}{$\begin{array}{l}\text { Has your doctor or other health } \\
\text { professional thoroughly explained } \\
\text { results of tests (e.g. blood pressure, } \\
\text { cholesterol)? }\end{array}$} & $\begin{array}{l}\text { Nil to a small } \\
\text { extent }\end{array}$ & $23(7)$ & $=7(5)$ & $1(2)$ & $9(9)$ & $7(7)$ & $32(8)$ \\
\hline & Moderate extent & $49(16)$ & $18(12)$ & $6(12)$ & $13(13)$ & $13(14)$ & $59(15)$ \\
\hline & $\begin{array}{l}\text { Large to great } \\
\text { extent }\end{array}$ & $236(77)$ & $121(82)$ & $42(86)$ & $76(76)$ & $75(79)$ & $313(77)$ \\
\hline & Total & 308 & 147 & 49 & 98 & 95 & 404 \\
\hline \multirow{4}{*}{$\begin{array}{l}\text { Has your doctor or other health } \\
\text { professional (e.g. nurse, dietician) } \\
\text { provided information on community } \\
\text { services, education or other } \\
\text { resources to assist you to manage } \\
\text { your health? }\end{array}$} & $\begin{array}{l}\text { Nil to a small } \\
\text { extent }\end{array}$ & $100(32)$ & $52(35)$ & $20(41)$ & $48(48)$ & $42(44)$ & $199(49)$ \\
\hline & Moderate extent & $79(26)$ & $41(28)$ & $12(24)$ & $17(17)$ & $27(28)$ & $92(23)$ \\
\hline & $\begin{array}{l}\text { Large to great } \\
\text { extent }\end{array}$ & $129(42)$ & $54(37)$ & $17(35)$ & $33(37)$ & $26(27)$ & $113(28)$ \\
\hline & Total & 308 & 147 & 49 & 98 & 95 & 404 \\
\hline
\end{tabular}

